\title{
A SZERVÁTÜLTETÉST KÖVETŐ ROSSZINDULATÚ DAGANATOK PROBLÉMÁJA, KÜLÖNÖS TEKINTETTEL A LYMPHOMÁBAN SZENVEDŐ, TRANSZPLANTÁLT BETEGEKNÉL VÁLASZTANDÓ IMMUNSZUPPRESSZÍV KEZELÉSRE. A MYCOPHENOLSAV, MINT LEHETŐSÉG
}

\author{
Végsö Gyula \\ Semmelweis Egyetem, Patológiai Tudományok Doktori Iskola, Budapest
}

\begin{abstract}
A krónikus immunszuppresszió mellett növekvő gyakorisággal kialakuló rosszindulatú daganatok a szervtranszplantált betegek hosszú távú túlélésének egyre fontosabb meghatározói. Hatékonyan szembeszállni e problémával csak akkor tudunk, ha ismerjük a betegeinkre vonatkozó jellegzetességeit. A veseátültetett recipienseink körében elöforduló daganatok incidenciája és gyakorisági sorrendje eltér a magyarországi lakosságétól. A krónikus veseelégtelenség és a vesére váró hazai betegek öregedéséból adódó fokozott daganatos kockázat, valamint a szervátültetés utáni korai időszakban általunk észlelt tumorok aránya alapján úgy véljük, hogy a daganattal történö veseátültetés kockázatát csak a várólistán lévő vesebetegek rendszeres onkológiai szemléletú ellenörzésével, a tumorok időben történö felismerésével lehet csökkenteni. A veseátültetés után a rákelötti állapotok és a daganatok korai felfedezése és kezelése, az alacsony dózisú és onkológiai szempontból kedvezőbb hatású immunszuppresszív vegyületek alkalmazása lehet az eszköze a daganatok okozta kockázat mérséklésének. A poszttranszplantációs tumorok prognózisa kedvezötlen, a kezelésre rosszul reagálnak. Gyakoriságuk miatt kiemelt jelentöségüek a lymphomák. Kialakulásukban a különbözó immunszuppresszív szerek eltérő kockázatot jelentenek. A mycophenolsav alkalmazása mellett ez a kockázat alacsonyabb. Az immunszuppresszió összetétele a kezelés egyik fontos kérdése; az onkológiai szempontból is ideális vegyület véd a kilökődési reakció ellen, ugyanakkor nem rontja az onkoterápia hatását. Vizsgálatainkkal igazoltuk, hogy a mycophenolsav in vitro és in vivo is gátolja a humán B-sejtes non-Hodgkinlymphomasejtek proliferációját, azokban az intrinsic út aktiválása révén apoptózist indukál. Kedvező tulajdonságai alapján úgy véljük, a mycophenolsav, mint immunszuppresszív szer hatékony védelmet nyújt a transzplantált szerv számára, ugyanakkor lymphoma elleni hatása révén segitséget jelenthet a lymphomában szenvedö betegek terápiájában is. Citosztatikus hatása alapján a nem transzplantált lakosság "hagyományos" lymphomáinak kezelésében is ajánlható, ahol a kemoterápia eredménytelenségének egyik legföbb oka éppen az apoptózissal szembeni rezisztencia kialakulása. A mycophenolsav más kemoterápiás szerekkel kombinálva felerôsitheti a lymphomasejtekben azok apoptózist indukáló hatását. Kedvezö kísérleti eredményeink alapul szolgálhatnak a további, klinikai vizsgálatokhoz. Magyar Onkológia 53: 149-156, 2009
\end{abstract}

Kulcsszavak: szervátültetés, immunszuppresszió, rosszindulatú daganat, lymphoma, mycophenolsav

The increasing frequency of malignant tumors developing during chronic immunosuppression is an important determinant of the long-term survival of organ transplanted patients. This problem can be solved only if we are aware of the special characteristics concerning our patients. The incidence and frequency of tumors occurring in kidney transplant recipients differ from those of the Hungarian population. The increased tumor risk resulting from chronic renal failure, increasing age of prospective kidney recipients and, in addition, the increasing frequency of tumors diagnosed in the early post-transplantation period emphasize the importance of regular oncological screening of patients on the waiting list. Early diagnosis and treatment of tumors and precancerous conditions are equally important in transplanted patients as well, and the tumor risk could be decreased by applying low dose immunosuppression and the preferential usage of immunosuppressive drugs
Levelezési cím: Dr. Végső Gyula SE Transzplantációs és Sebészeti Klinika 1082 Budapest Baross u. 23-25. Telefon: (06-1) 267-6000 Fax: (06-1) 317-2166 E-mail: vegso@trans.sote.hu

Témavezetó: Dr. Kopper László 
with an oncologically favorable effect. The prognosis of post-transplantation tumors is poor, as they respond poorly to therapy. Lymphomas are of great importance because of their frequency. Different immunosuppressive regimens represent varying degrees of risk in lymphoma development. This risk is lower in the case of mycophenolic acid. The composition of immunosuppression is a major factor in treatment; an oncologically ideal compound would prevent organ rejection and, at the same time, would not counteract oncological therapy. We have shown that mycophenolic acid inhibits the proliferation of human B-cell non-Hodgkin lymphomas and induces apoptosis by activating the intrinsic pathway, both in vitro and in vivo. The favorable properties of mycophenolic acid suggest that it can provide the necessary immunoprotection for the transplanted organ and, given its anti-lymphoma effects, it may also prove useful in the therapy of lymphoma patients. It may also be helpful in the treatment of "traditional" lymphomas of the non-transplanted population, where the major cause of therapeutical failure is the development of apoptosis resistance. Mycophenolic acid, combined with other chemotherapeutical drugs, may enhance apoptosis in lymphoma cells. Our promising experimental results provide a basis for further, clinical studies. Végső G. Posttransplantation malignant tumors and the challenges of immunosuppressive therapy in transplantanted patients developing lymphoma. Mycophenolic acid - a possibility. Hungarian Oncology 53: 149-156, 2009

Keywords: organ transplantation, immunosuppression, malignant tumor, lymphoma, mycophenolic acid

\section{BEVEZETÉS}

Ismert, hogy a rosszindulatú daganatok a szervtranszplantált betegek körében gyakoribbak, mint a lakosságban. A poszttranszplantációs daganatok összetétele eltér a populációra jellemző tumorokétól. Kialakulásuk kockázata 2-4-szerese, de bizonyos daganatok esetén akár 100-szorosa is lehet a népesség hasonló daganatainak. Létrejöttükben az egyik legfontosabb rizikótényező az immunszupprimált állapot, melynek idejével arányosan növekszik a daganatok kialakulásának a valószínüsége. A szervátültetést követően a 10 éves daganatos kumulatív incidencia 20\%, a 20 éves 30-40\%. A poszttranszplantációs tumorok az onkológiai kezelésre rosszabbul reagálnak, és prognózisuk is rosszabb, mint a lakosság hasonló daganataié. A szervátültetést követő rosszindulatú daganatok növekvő gyakoriságuk és kedvezőtlen prognózisuk miatt a transzplantált betegek sorsának, túlélésének egyik legfontosabb meghatározó tényezőjévé kezdenek válni. A betegek halálozásában vezető szerepet játszó kardiovaszkuláris tényezők mellé már több transzplantációs centrumban felzárkóztak a daganatok. A poszttranszplantációs tumorok tehát komoly problémát jelentenek, mellyel egyre gyakrabban kell nekünk is szembenézni. Ahogy a lakosság daganatai a világ különböző pontjain eltérő jellegzetességeket mutatnak, ugyanúgy vannak helyi sajátosságai a poszttranszplantációs tumoroknak is. Hatékonyan szembeszállni e problémával csak akkor tudunk, ha az irodalmi adatokon túl ismerjük a reánk jellemző sajátosságait is.

A szervátültetést követő daganatok közül gyakorisága és rossz prognózisa miatt a legfontosabbnak a lymphomát kell tekintenünk. Felnőtt korban a bőrrák után a második, gyermekkorban a leggyakoribb daganat. Kialakulásának kockázata 20-120-szorosa a nem transzplantált lakosságénak. Döntően B-sejtes eredetü és Epstein-Barr-vírushoz asszociált. A kezelésre rosszul reagál, az 5 éves túlélés 30\%-os. Kezelési lehetôségei érdemben nem különböznek a nem transzplantált lakosság „hagyományos” lymphomáinak ellátásától. A terápia fontos kérdése, hogy mi történjék az immunszuppresszióval. A kezelés kezdetekor mindenképp ajánlott az adagját csökkenteni, vagy elhagyni. A kezelés eredményeként remisszióba kerülő betegnél azonban a transzplantált szerv védelme érdekében valamilyen immunszuppresszióra szükség van. Az ideális az olyan immunszuppresszív vegyület lenne, mely védelmet tud nyújtani a graft számára a kilökődési reakció ellen, ugyanakkor nem rontja az onkológiai kezelés eredményét, nem fokozza a relapszus kockázatát. Antiproliferatív hatása alapján az irodalom erre a célra a rapamycint ajánlja. A rapamycin sem elegendő azonban önmagában, annak is megvannak az ismert mellékhatásai, ellenjavallatai. Szükség van tehát egyéb, ebben a helyzetben is alkalmazható immunszuppresszív gyógyszerre. További szakmai ajánlás azonban egyelőre nincs, a lymphomában szenvedő szervtranszplantált betegek immunszuppressziójának kérdése tehát nem megoldott. A megoldást keresve került érdeklődésünk középpontjába a mycophenolsav, mely immunszuppresszív hatását az aktivált lymphocyták "de novo" purinnukleotid-szintézisének gátlásával fejti ki. Sejtproliferáció-gátló, antimetabolit vegyület. Ha igazolódna, hogy a lymphocytákban észlelt gátló hatása a lymphomasejtekben is érvényesül, akkor lymphomaellenes tulajdonsága révén a siker reményében alkalmazhatnánk a lymphomában szenvedő transzplantált betegek, és tágabb értelemben véve is, a nem transzplantált lakosság „hagyományos” lymphomáinak kezelésében. 


\section{CÉLKITUUZÉSEK}

1. A veseátültetést követően kialakuló rosszindulatú daganatok „hazai” jellegzetességeinek megismerése, és a betegellátást segítő következtetések megfogalmazása a Budapesten 33 év alatt végzett, közel 2900 veseátültetés adatai alapján.

2. A lymphomában szenvedő szervtranszplantált betegek immunszuppresszív kezelésének problémája, és a mycophenolsav lymphocytaproliferációt gátló hatása alapján a mycophenolsav különböző humán B-sejtes non-Hodgkin-lymphomákra gyakorolt hatásának in vitro és állatkísérletes vizsgálata.

\section{MÓDSZEREK}

Betegek és módszerek a veseátültetések után észlelt rosszindulatú daganatok adatainak elemzésére

A vizsgált időszak az első budapesti veseátültetés napjától, 1973. november 16-tól 2006. december 31-ig terjed. A Semmelweis Egyetem transzplantációs munkacsoportja ez idő alatt 2852 veseátültetést végzett. 2535 beteg részesült először, 294 másodszor, 23 pedig harmadszor vesetranszplantációban.

A veseátültetést követően a betegeket az erre a célra kialakított ambulancián ellenőrizzük mindaddig, míg a betegek vesegraftja működik. Szövődmény esetén a betegeket saját nefrológiai-transzplantációs osztályunkra tudjuk felvenni. A betegekkel kapcsolatos adatokat, beleértve a rosszindulatú daganatokra vonatkozóakat is, számítógépes adatbázisban rögzítjük. Retrospektív feldolgozásunk is erre az adatbázisra épül. Az ellenőrzött járóbetegek száma aktuálisan változó, 2007 januárjában 1300 beteget kontrolláltunk működő grafttal. Az összes vesetranszplantált beteg $2 \%$-a esett ki a követésből. A daganatos betegek esetén az átlagos követési idő 94,1 hónap volt.

188 betegben észleltük rosszindulatú daganat kialakulását. A férfi:nő arány 2,19:1 (129/59) volt. A betegek átlagéletkora 53,1 $\pm 10,1$ évnek bizonyult, a férfiak idősebbek voltak $(54,3 \pm 10,0$ év), mint a nők $(51,4 \pm 9,9$ év), a különbség szignifikáns $(\mathrm{p}=0,017)$. 170 beteg részesült először, 18 pedig másodszor veseátültetésben. A donor és recipiens közötti HLA-eltérés átlagosan 2,83ะ0,6 volt.

A veseátültetés utáni, és a magyar lakosság körében előforduló rosszindulatú daganatok incidenciáját a Magyar Nemzeti Rákregiszter adatai alapján hasonlítottuk össze.

A daganatos betegek az alkalmazott immunszuppresszív kezelés alapján 4 csoportba oszthatók:

I. csoport: Azathioprine+szteroid ( $\mathrm{n}=16,8,5 \%)$,

II. csoport: Cyclosporine+szteroid ( $\mathrm{n}=111,59,0 \%$,

III. csoport: Cyclosporine+mycophenolate

mofetil+szteroid ( $n=50,26,6 \%)$,

IV. csoport: Tacrolimus+mycophenolate mofetil+szteroid $(\mathrm{n}=11,5,9 \%)$.
A magyarországi vesetranszplantációs program 1973-ban indult. Az I. csoport betegei az úgynevezett konvencionális immunszuppresszióban részesültek. Ezt váltotta fel a cyclosporine 1984-ben (II. csoport), majd 1997-ben egészült ki a cyclosporine+szteroid kombináció a mycophenolate mofetil-lel (III. csoport). 2000től használjuk a vesetranszplantált betegek esetében is a tacrolimust (IV. csoport). Indukciós kezelést, immunterápiát (OKT3, ATG, anti-CD25 monoklonális ellenanyagok) második veseátültetésben részesülő betegek esetében végeztünk.

Az adatok elemzéséhez leíró statisztikát (n, átlag, SD) alkalmaztunk. Az egyes csoportok adatainak összehasonlításához a Fischer t-tesztet, a varianciaanalízishez az egyszempontú ANOVA módszert használtuk. A szignifikanciát a Student $t$-teszt segítségével határoztuk meg. Szignifikáns eltérésnek a $\mathrm{p}<0,05$ értéket tekintettük. A túlélésanalízis Kaplan-Meier-módszerrel, a betegcsoportok túlélésének összehasonlítása a logrank-teszt segítségével történt. A statisztikai analízist a SAS version 8.2 for Windows (SAS Institute Inc., Cary, NC, USA) programcsomag felhasználásával végeztük.

\section{Módszerek a mycophenolsav, mint immunszuppresszív szer humán non-Hodgkin-lymphomákra gyakorolt hatásának in vitro és állatkísérletes vizsgálatára}

Sejttenyésztés. A kísérletek során HT58 (EBV-), BL41 (EBV-), BL41/95 (EBV+) humán Burkitt-típusú B-sejtes non-Hodgkin-lymphoma sejtvonalakat, MED-B1 humán diffúz nagy B-sejtes non-Hodgkin-lymphoma (DLBCL) sejtvonalat, U266 myeloma sejtvonalat használtunk. A sejteket RPMI-1640 médiumban (Sigma, St Louis, MO, USA), 10\% FCS (Sigma) és penicillin-streptomycin (100 U/ml-100 $\mu \mathrm{g} / \mathrm{ml}$, Sigma) jelenlétében tenyésztettük. A 0-72 órás, in vitro kezelésekhez mycophenolsav (mycophenolic acid, MPA) (Sigma, 500 mM, DMSO-ban oldva), valamint guanozin (Sigma, $4 \mathrm{mM}$, vízben oldva) törzsoldatokat használtunk, ezeket $-20^{\circ} \mathrm{C}$-on tároltuk. Kísérleteink során az MPA $(0,05-50 \mu \mathrm{M})$ és a guanozin $(0,1-100 \mu \mathrm{M})$ koncentráció- és időfüggő hatásait 1-2×10 sejt/ml induló sejtszám mellett 24-es sejttenyésztő tálcán és T25-ös tenyésztő flaskában vizsgáltuk. Minden esetben legalább három független kísérletsorozatot végeztünk, minimum 3 párhuzamos vizsgálattal.

Áramlási citometriai vizsgálatok: sejtciklus, apoptózis, mitokondriummembrán-depolarizáció. Az apoptózis meghatározásához a sejteket $-20^{\circ} \mathrm{C}$-on, $70 \%$-os etanolban fixáltuk, majd lúgos extrakció (200 mM Na $\mathrm{HPO}_{4^{\prime}}$ pH 7,4, $1 \mu \mathrm{g} / \mathrm{ml}$ RN-áz A - Sigma) és ethidium-bromid festés (10 $\mu \mathrm{g} / \mathrm{ml}$, Sigma) segítségével készítettük elő a mintákat a méréshez. Kísérleteinkben a sejtciklus változásait és az apoptózis mértékét áramlási citometriával (FACS) detektáltuk (BD Biosciences, Erembodegem, Belgium).

A mitokondriummembrán-depolarizáció mértékének meghatározásakor $5 \times 10^{5}$ natív sejt $\mathrm{DiOC}_{6}(10 \mathrm{nM}$, 
Molecular Probes) és propidium-jodid ( $5 \mu \mathrm{g} / \mathrm{ml}$ ) festését követően, a mérhető fluoreszcenciaintenzitásbeli változás detektálását 530-620 nm-en, szintén flow citometria segítségével végeztük el. Az eredmények kiértékelését WinList (Verity Software House, Topsman, ME, USA) programmal végeztük.

Kaszpáz 2- és kaszpáz 3-aktiváció vizsgálata. 0,5×105ejtet kaszpáz pufferoldatban (50 mM HEPES, $100 \mathrm{mM}$ $\mathrm{NaCl}, 0,1 \%$ (w/v) CHAPS, $10 \%$ (w/v) sucrose $+10 \mathrm{mM}$ DTT) vettük fel. A sejteket azonos térfogatú puffer (0,2\% Triton X-100) és pipettázás segítségével lizáltuk. A kaszpáz 2 aktivitását 0-200-1000 nM zVAD-fmk (Sigma) kaszpázinhibitor jelenlétében (gátolja a nem specifikus kaszpázaktivitások hatását a szubsztráton) Ac-VDVAD-afc (50 $\mu \mathrm{M}$, Bachem) szubsztrát segítségével határoztuk meg. Ac-DEVD-amc kaszpáz 3-szubsztrát (50 $\mu \mathrm{M}$, Bachem Weil, Németország) hozzáadásával a kaszpáz 3 aktivitását mértük. A felszabaduló fluoreszcenciaintenzitásokat fluorescence plate reader (Fluoroscan Ascent Fluorimeter, Thermo Electron Corp, Waltham, MA, USA) segítségével 15 és 20 perces inkubációs idővel 390/460 nm-en és 400/505 nm-en detektáltuk. Az eredmények és a kalibrációs görbe értékelése Microcal Origin Software segítségével történt. Pozitív kontroll vizsgálatként a staurosporin (6 h, $1 \mu \mathrm{M}$, Sigma) által HL60 sejtekben indukált apoptózis ill. kaszpázaktivitás meghatározása szolgált.

Xenograft tumorok. Xenograft tumorokat immunhiányos SCID egerekben hoztunk létre. Röviden: $2 \times 10^{7}$ tumorsejtet 8-10 hetes SCID egerek (20-23 g) hátának bőre alá (subcutan - sc.) oltottuk be. A kontroll állatokban az oltást követő 10-13. napon váltak a tumorok tapinthatóvá. In vivo kísérleteinkben a kezeléshez mycophenolate mofetilt (MMF) (Cellcept $250 \mathrm{mg}$ capsule, Roche, Basel, Svájc) alkalmaztunk, a korábban már leírt és alkalmazott $100 \mathrm{mg} / \mathrm{kg}$-os napi egyszeri adagban, per os, szonda segítségével $200 \mu$ l fiziológiás sóoldatban beadva. A kontroll állatok $200 \mu$ l fiziológiás sóoldatot kaptak szondán keresztül, naponta egyszer. A kontroll és az MMF-fel kezelt állatok száma kísérletenként $10-10$ volt.

A növekvő tumorok térfogata a tumorok átmérői alapján, a következő képlet segítségével került kiszámolásra: $\pi / 6 x(2 x$ rövid átmérő+hosszú átmérő $) / 3)^{3}$. A kísérletek végén, az állatok túlaltatása után, a tumorokat eltávolítottuk és tömegüket megmértük.

Az MMF hatásának vizsgálata kétféle kezelési protokoll szerint történt.

A kezelést az oltást követően 24 órával kezdtük el és végeztük naponta, folyamatosan, a kísérlet végéig.

A kezelést a sc. tumorok tapinthatóvá válása után a 13. napon kezdtük el és végeztük naponta, folyamatosan, a kísérlet végéig.
$\mathrm{Az}$ állatokat az állattartási és kísérleti törvényeknek megfelelően, légkondicionált állatházban tartottuk $\left(55 \%\right.$ relatív páratartalom, $25^{\circ} \mathrm{C}, 12 / 12$ órás sötét/világos ciklusok). Minden vizsgálatot az állatház hivatalos engedélyének megfelelően végeztünk (eng. szám: 399/003/2005).

Immunhisztokémiai vizsgálatok. A lymphomasejtek proliferációs és apoptotikus aktivitását a xenograft tumorokban is meghatároztuk. A kontroll és MMF-kezelt állatokból eltávolított tumorokból formalinos fixálás után paraffinos blokkokat készítettünk. A kontroll és MMF-kezelt állatok egy részének hasüregébe $100 \mathrm{mg} /$ kg bróm-dezoxiuridint (BrdU) (Sigma) fecskendeztünk a kísérlet befejezése előtt egy órával. Ezekből az állatokból az eltávolított tumorokat $60 \%$ etanol + $10 \%$ formaldehid oldatban fixáltuk a paraffinba ágyazás előtt. Immunhisztokémiai vizsgálatokat végeztünk monoklonális anti-Ki67 (Dako, Glostrup, Dánia), anti-cleaved caspase 3 (Cell Signaling, Beverly, MA, USA) elsődleges ellenanyagok és streptavidin-biotin peroxidase system (Dako) segítségével Ventana ES automatában (Ventana Medical Systems, Inc., Cedex, Franciaország). A metszeteken monoklonális anti-BrdU ellenanyag (Becton-Dickinson), Vector Elite ABC kit festéseket végeztünk.

A mitotikus, proliferáló és apoptotikus sejtek arányát a Ki67, a BrdU és aktív kaszpáz 3 (cleaved caspase 3) pozitív tumorsejtek számolásával, és a H\&E metszetek kiértékelésével (x400) határoztuk meg, metszetenként 1000-1000 sejten. Csak a tumorszövetek olyan részleteit vizsgáltuk, amelyekben stromaelemek és nekrotikus területek nem voltak. Az értékelést két független vizsgáló végezte.

Lymphomasejtek izolálása xenograft tumorokból és in vitro tenyésztésük. Az eltávolított kontroll és kezelt tumorok kézi feldarabolása után a mononukleáris sejtek szuszpenzióját Ficoll-gradienscentrifugálással (Histopaque 1077, Sigma) tisztítottuk. A lymhomasejtekben feldúsult sejtszuszpenziót anti-humán CD19-MACS microbeads (Miltenyi) ellenanyaggal jelöltük, majd ezt követően MACS Columns (Miltenyi Biotec, Bergisch Gladbach, Németország) oszlopok segítségével elválasztottuk a nem lymphomasejtektől. A humán CD19 elleni ellenanyaggal jelölt sejteket eluálásukat követően 2 hétig in vitro tenyésztettük, majd ezt követően teszteltük MPAérzékenységüket in vitro.

Statisztikai analizis. Az adatok elemzéséhez leíró statisztikát (n, átlag, SD) alkalmaztunk. A szignifikanciát a Student $t$-teszt segítségével határoztuk meg. Szignifikáns eltérésnek a $\mathrm{p}<0,05$ értéket tekintettük. A statisztikai analízist a SAS version 8.2 for Windows (SAS Institute Inc., Cary, NC, USA) programcsomag felhasználásával végeztük. 


\section{EREDMÉNYEK}

\section{Eredmények a veseátültetések után észlelt rosszindulatú daganatok adatainak elemzésekor}

A veseátültetést követôen észlelt rosszindulatú daganatok fajtái, incidenciája. Az 1973. november 16. és 2006. december 31. között veseátültetésben részesült 2535 betegből 188-ban észleltünk 193 rosszindulatú daganatot. A tumorok gyakorisága 7,6\% volt. A leggyakoribb daganatok a következők voltak: bőrrák $(n=51)$, veserák $(n=26)$, tüdőrák ( $n=15)$, Kaposi-sarcoma ( $n=12)$, emlőrák ( $n=12)$, non-Hodgkin-lymphoma $(n=10)$, májrák $(n=7)$, pajzsmirigyrák $(n=6)$, vastagbél- ill. végbélrák $(n=6)$, melanoma malignum $(n=6)$. A veseátültetés utáni első négy évben előforduló daganatok kumulatív incidenciáját a Nemzeti Rákregiszter 2001-2004 évi adatai alapján összehasonlítottuk a magyarországi, nem transzplantált lakosság tumorainak gyakoriságával. Az adatokból kitünik, hogy a magyar lakosságra jellemző, gyakori daganatok közül csak a bőr- és gyomorrák mutat magasabb arányt $(2,58 x, 1,61 x)$ a vesetranszplantált betegek körében, ugyanakkor a tüdő-, a vastagbél-, a szájüregiés prostatarák incidenciája alacsonyabb $(>30 \%)$, mint a nem transzplantált populációban. A lymphomák gyakorisága csak alig volt magasabb a transzplantáltaknál, ami azzal magyarázható, hogy a lymphomák többsége több mint 5 évvel a veseátültetés után jelent meg. A Kaposi-sarcoma gyakori volt a transzplantált betegek daganatai között (6,2\%), a Nemzeti Rákregiszter azonban erről a daganatról nem közöl adatot. A veseátültetés után lényegesen magasabbnak bizonyult a máj-, vese-, pajzsmirigyrák incidenciája $(3,25 x, 6,77 x, 8,95 x)$ a magyar lakossághoz képest.

A négy különböző immunszuppresszív kezelésben részesülő betegcsoport összehasonlítása az életkor és a daganatok megjelenési ideje szerint. Az ANOVA analízis alapján az egyes csoportok szignifikáns mértékben különböztek egymástól mind a betegek átlagéletkorát tekintve $(p<0,003)$, mind pedig a daganatok megjelenéséig eltelt átlagidő alapján $(\mathrm{p}<0,0001)$. A betegek átlagéletkora a veseátültetés időpontjában és a daganatok felismerésekor, a kezdetektől (I. csoport) napjaink felé (IV. csoport) haladva növekszik. A magyarországi vesetranszplantációs program kezdetekor még fiatal betegeket transzplantáltunk (az I. csoport átlagéletkora 37,1 77,4 év). A 2000. év utáni betegeket reprezentáló IV. csoport átlagéletkora szignifikánsan magasabb, 56,0 $\pm 8,3$ év. Másik megfigyelésünk, hogy az időben egymást követő négy különböző immunszuppressziót kapott betegcsoportban a daganatok megjelenésének átlagideje egyre rövidül. A daganatok egyre korábbi megjelenése a betegek átlagéletkorának növekedésével, az öregedéssel nem mutat szignifikáns összefüggést $(p<0,14)$, viszont statisztikailag szignifikáns a kapcsolata az immunszuppresszió változásával $(\mathrm{p}<0,0001)$.
A veseátültetés és a daganatok felismerése között eltelt idő. A veseátültetés és a daganatok felismerése kö-

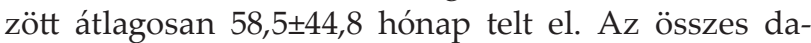
ganatot figyelembe véve a tumorok $11,4 \%$-a $(n=22)$ a vesetranszplantációt követően 6 hónapon, 20,2\%-a $(n=39) 1$ éven belül került felismerésre. A daganatok $35,2 \%-a(n=68)$ jelent meg 2 éven, 93,3\%-a $(n=180) 10$ éven belül, 6,7\%-a (n=13) pedig 10 év után. A gyakoribb daganatok közül a veserák 38,4\%-a, a tüdőrák 20,0\%-a, az emlőrák 33,4\%-a, a Kaposi-sarcoma 58,3\%-a jelent meg a veseátültetés utáni első évben. Ugyanakkor lymphomát nem észleltünk ilyen rövid idő elteltével. A veseátültetést követő első évben megjelent daganatok aránya a különböző immunszuppresszió szerinti csoportokban: I. csoport 12,5\% (2/16), II. csoport 18,9\% (21/111), III. csoport 22,0\% (11/50), IV. csoport pedig 45,5\% (5/11).

A daganatos vesetranszplantált betegek halálozási adatai. A 188 daganatos betegből 92 halt meg a vizsgált időszakban (48,9\%). Az elhunyt betegek átlagéletkora $54,8 \pm 10,4$ év, átlagos túlélési idejük a daganat felisme-

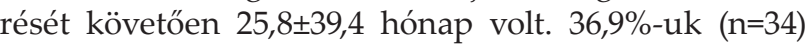
hunyt el a tumor diagnosztizálását követő 6 hónapon belül, 55,4\%-uk (n=51) az első évben, 70,6\%-uk (n=65) két éven belül, $84,7 \%$-uk $(\mathrm{n}=78)$ pedig öt éven belül. A halálok a betegek $32,6 \%$-ában $(n=30)$ daganatos progresszió, 30,4\%-nál (n=28) fertőzéses szövődmény (pneumonia, sepsis) volt. A többi 34 elhunyt beteg (37\%) esetében cardialis, cerebrovascularis szövődmény, tüdőembolia, májcirrhosis, májelégtelenség, acut pancreatitis, tuberculosis volt a halál kiváltó oka. A vizsgált időszak végén életben lévő, 96 daganatos beteg átlagos követési

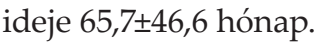

A daganatos vesetranszplantált betegek túlélési adatai. Kaplan-Meier módszerrel meghatározva a 188 beteg túlélési arányait, az 1 éves túlélés 69,5\%, a 2 éves $61,8 \%$, a 3 éves $57,3 \%$, az 5 éves túlélés pedig $52 \%$. A túlélés a bőrrák esetében a legjobb, az 1 éves 90,2\%, az 5 éves $75,9 \%$. A többi daganat prognózisa összesítve rosszabb, az 1 éves túlélés 59,2\%, az 5 éves pedig 38\%. A két nemet összehasonlítva, a férfiak 1 éves túlélése $63,8 \%$, az 5 éves $46,3 \%$, míg ugyanez a nők esetében $81,3 \%$ és $60,4 \%$. A nők túlélési aránya szignifikánsan magasabb, mint a férfiaké $(p=0,0138)$.

Eredmények a mycophenolsav, mint immunszuppresszív szer humán non-Hodgkin-lymphomákra gyakorolt hatásának in vitro és állatkísérletes vizsgálatakor

A vizsgálatokat a Semmelweis Egyetem I. sz. Patológiai és Kísérleti Rákkutató Intézetében végeztük el.

A mycophenolsav sejtproliferációt gátló és apoptózist indukáló hatása. A mycophenolsav az idő és a koncentráció függvényében, valamennyi vizsgált sejtvonal esetében gátolta a sejtproliferációt és apoptózist indukált. A Burkitt-lymphoma sejtvonalak esetében a proliferációt 
gátló hatás a kezelést követően 24 órával már észlelhető volt, a sejtek a sejtciklus G1/S fázisának átmenetében halmozódtak fel. A ciklusban továbblépő sejtek 64 óra elteltével az S/G2 fázis határán blokkolódtak. 72 óra után apoptotikus katasztrófa/sejtpusztulás volt megfigyelhető. A mycophenolsav iránti érzékenységben az EBVpozitív és EBV-negatív Burkitt-lymphomák között nem volt különbség. A DLBCL lymphomasejtvonal esetében az MPA sejtproliferációt gátló hatása még kifejezettebb volt, a blokk a sejtciklus G2 fázisa előtt érvényesült, de az apoptózis indukciójához hosszabb kezelési időre volt szükség. 96 óra elteltével az apoptózis aránya a kontroll sejtekben $2 \pm 0,5 \%$, az $5 \mu \mathrm{M}$ koncentrációjú MPA mellett pedig $21 \pm 1 \%$ volt. A mycophenolsav a myeloma-sejtvonal esetében is gátolta a sejtproliferációt. 72 óra kezelési idő után az apoptotikus sejtek aránya a kontroll sejtekben $9 \pm 2 \%$, az MPA-kezelés $(5 \mu \mathrm{M})$ mellett pedig $65 \pm 4 \%$ volt.

Az MPA lymphomasejtvonalakra gyakorolt hatását guanozin jelenlétében is vizsgáltuk. A guanozin 0,1-100 $\mu \mathrm{M}$-os koncentrációban alkalmazva nem függesztette fel a mycophenolsav (5 $\mu \mathrm{M})$ lymphomasejtekre gyakorolt antiproliferatív és apoptotikus hatását.

A mycophenolsav indukálta apoptózis mechanizmusának vizsgálata. Az MPA indukálta apoptózis mechanizmusának vizsgálatakor a mitokondriummembrándepolarizációt, a kaszpáz 2 és kaszpáz 3 enzimek aktiválódását, valamint a bcl-2 és bax fehérje szintjének változását mértük. A mitokondriális depolarizáció megjelenése időben egybeesett az apoptózis indukálódásával, majd maximumát 48 óra elteltével érte el. Az apoptózis aktiválódásában a mitokondriális út szerepe mellett szól az anti-apoptotikus hatású bcl-2 fehérje szintjének egyidejü csökkenése is. Az apoptózist iniciáló kaszpáz enzimek közül a kaszpáz 2 aktiválódása, szemben az irodalomban olvasható, más sejtvonalra vonatkozó közléssel, nem volt kimutatható. Az apoptózist végrehajtó, effektor kaszpázok közé tartozó kaszpáz 3 enzim aktiválódását a mitokondriális indukció után, az MPAkezelés 40. órájában észleltük.

A mycophenolsav lymphoma xenograftok növekedését gátló hatása. Az oltást követő első naptól alkalmazott MMF-kezelés eredményeként a tumornövekedés a HT58, BL41 és BL41/95 lymphomák esetében egyaránt jelentősen elmaradt a kontrollokhoz képest. A kísérletek végén eltávolított, MMF-kezelt tumorok átlagsúlya szignifikánsan alacsonyabb volt, mint a kontroll tumoroké, azok 15-24\%-a. Hasonlóan szignifikáns különbség mutatkozott a kontroll és az MMF-kezelt tumorok idő függvényében meghatározott, kalkulált térfogatai között. Az oltást követő 25. nap után a tumortérfogatok drámai növekedését észleltük a kontroll állatokban, ami az MMF-kezelt csoportban nem volt megfigyelhető. Az MMF tumornövekedést gátló hatását észleltük akkor is, amikor a kezelést a lymphomasejtek oltását követően csak később, a tumorok tapinthatóvá válása utáni 13. naptól kezdtük alkalmazni. A kísérletek végén megha- tározva az eltávolított tumorok súlyainak és térfogatainak átlagát, az MMF-kezelt csoportban szignifikánsan alacsonyabb értékeket kaptunk.

A kontroll és MMF-kezelt xenograft tumorokat a kísérletek végén eltávolítottuk. A fixálást és paraffinba történt beágyazást követően készített szövettani metszeteken a sejtproliferáció aktivitásának és az apoptózis mértékének meghatározásához hematoxilin-eozin festést és immunhisztokémiai vizsgálatokat végeztünk. A sejtproliferációs aktivitást a BrdU- és Ki67-pozitív sejtek arányával, az apoptózis mértékét pedig az aktív kaszpáz 3-ra pozitív (a hematoxilin-eozin festés alapján apoptotikus morfológiát mutató) sejtek arányával jellemeztük. Az MMF-kezelt tumorokban szignifikánsan alacsonyabb proliferációs és szignifikánsan magasabb apoptotikus aktivitást észleltünk.

28 napos MMF-kezelést követően a sc. Burkittlymphoma xenograft tumorokból több lépcsős izolálási eljárás révén a lymphomasejteket in vitro tenyészetbe vittük vissza. Az így nyert „,új” sejtvonalakat tovább tenyésztettük, majd mycophenolsavval kezeltük. Arra kerestük a választ, hogy az in vivo MMF-kezelés mellett túlélő lymphomasejtek elvesztették-e a mycophenolsav iránti érzékenységüket. 72 órás MPA $(5 \mu \mathrm{M})$ kezelés után a mycophenolsav sejtproliferációt gátló és apoptózist indukáló hatását észleltük mind a három „új”" sejtvonal esetében. Az apoptotikus sejtek aránya 45-60\% közötti volt. A lymphomasejtek in vitro vizsgálva megőrizték a mycophenolsav iránti érzékenységüket az in vivo MMF-kezelést követően.

\section{KÖVETKEZTETÉSEK}

A veseátültetést követően észlelt rosszindulatú daganatok adatainak elemzéséből levonható következtetések, megállapítások

1. Igazoltuk, hogy veseátültetett betegeink körében a magyarországi, nem transzplantált lakossághoz képest a rosszindulatú daganatok gyakrabban fordulnak elő. Eredményeink az irodalmi adatokat tükrözik.

2. Hazánkban elsőként végeztük el a veseátültetés utáni, és a magyarországi, nem transzplantált lakosság körében előforduló, gyakoribb rosszindulatú daganatok incidenciájának meghatározását, azok összehasonlítását és az eredmények nemzetközi közlését.

3. Eredményeink alapján megállapíthatjuk, hogy a magyar lakosság gyakori tumorai közül a veseátültetés után csak a bőrrák és a gyomorrák mutatott - mérsékelten - magasabb előfordulási arányt, a tüdő-, vastagbél-, végbél-, emlő-, szájüregi és prostatarák incidenciája ugyanakkor alacsonyabb volt.

4. Az eltérő összetételű immunszuppresszív kezelésben részesült, kronológiailag egymást követő betegcsoportokban a daganatok megjelenésének átlagideje egyre rövidült. Ennek magyarázata lehet az 
immunszuppresszió különbözősége, az eltérő esetszám és betegkövetési idő miatt azonban egyértelmű megállapítás még nem tehető.

5. A veseátültetést követő első évben észleltük a daganatok közel 20\%-át. Ennek azért kell jelentőséget tulajdonítanunk, mert a korai időszakban megjelenő daganatokról feltételezhető, hogy vagy még fel nem ismerhetően, vagy fel nem ismerten, de már a transzplantáció időpontjában jelen vannak a betegekben.

6. Betegeink átlagéletkora a veseátültetés időpontjában és a daganatok felismerésekor, 1973-tól napjainkig követve, egyaránt folyamatosan növekszik. A vesebetegek öregedése növeli a daganatok kialakulásának kockázatát.

7. Hazánkban elsőként határoztuk meg és közöltük nemzetközi folyóiratban a veseátültetett daganatos betegek összesített és tumorspecifikus, 1 és 5 éves túlélési eredményeit. Ezek alapján a bőr- és pajzsmirigyrák bizonyult a legkedvezőbb prognózisúnak, a Kaposi-sarcoma, tüdő-, májrák és a non-Hodgkinlymphoma pedig a legrosszabbnak. A nők jobb túlélési eredményeit azzal magyarázhatjuk, hogy körükben a rossz prognózisú daganatok ritkábban fordultak elo".

8. A krónikus veseelégtelenség és a vesebetegek öregedése miatt fokozódó daganatos kockázat, valamint a veseátültetés után észlelt korai tumorok aránya alapján úgy ítéljük meg, hogy a daganattal történő veseátültetés elkerülése érdekében, a vesetranszplantációs várólistán lévő recipiensjelöltek rendszeres onkológiai ellenőrzése szükséges.

9. Javaslatot dolgoztunk ki a veseátültetésre váró, és a már vesetranszplantált betegek rendszeres onkológiai ellenőrzésének módjára, melyet előadásokban, hazai és nemzetközi közleményekben tettünk közzé.

10. Eredményeink alapján határoztuk meg a szervátültetést követő rosszindulatú daganatok kockázatának csökkentését szolgáló feladatainkat. Kiemelkedő fontosságúnak tartjuk a karcinogén hatások elkerülését célzó betegtájékoztatást, a rendszeres, onkológiai jellegű vizsgálatokat a rákelőtti állapotok és a daganatok korai felismerése és kezelése érdekében, valamint a krónikus immunszuppresszió okozta rizikó mérséklését a graft védelmét még biztosító, de alacsony gyógyszeradagok és az onkológiai szempontból kedvezőbb hatású vegyületek alkalmazásával.

A mycophenolsav, mint immunszuppresszív szer humán non-Hodgkin-lymphomákra gyakorolt hatásának vizsgálati eredményei alapján levonható következtetések, megállapitások

1. Elsőként igazoltuk és közöltük, hogy a mycophenolsav in vitro gátolja az általunk vizsgált lymphomasejtek proliferációját.
2. Elsőként igazoltuk és közöltük, hogy a mycophenolsav in vitro a lymphomasejtekben apoptózist indukál.

3. Elsőként igazoltuk és közöltük, hogy a mycophenolsav a lymphomasejtekben az apoptózist az intrinsic (mitokondriális) útvonal aktiválásával indukálja.

4. Igazoltuk és közöltük, hogy a guanozin jelenléte nem függeszti fel a mycophenolsav proliferációt gátló és apoptózist indukáló hatását a lymphomasejtekben, a guaninnukleotid-képzésben a salvage mechanizmus a lymphocytákhoz hasonlóan a lymphomasejtekben sem müködik.

5. Elsőként igazoltuk és közöltük, hogy a mycophenolsav in vivo szignifikáns mértékben gátolja az általunk vizsgált lymphomák növekedést. Hatása akkor is érvényesül, ha a kezelést a már kialakult tumorok esetében kezdjük el.

6. Elsőként igazoltuk és közöltük, hogy a mycophenolsav in vivo is apoptózist indukál a lymphomasejtekben.

7. Elsőként igazoltuk és közöltük, hogy az in vivo tumorokból in vitro tenyészetbe visszavitt lymphomasejtekben nem alakult ki rezisztencia a mycophenolsavval szemben.

8. A mycophenolsavat az általunkigazolt, humán B-sejtes non-Hodgkin-lymphomákra gyakorolt, sejtproliferációt gátló és apoptózist indukáló hatása alapján ajánlhatjuk a nem transzplantált lakosság „hagyományos” lymphomáinak kezelésében és a szervátültetés után kialakult lymphomák esetén, a betegek terápiájának és immunszuppressziójának megválasztásakor.

\section{SAJÁT PUBLIKÁCIÓK JEGYZÉKE}

\section{A doktori értekezéshez kapcsolódó közlemények}

1. Végső G, Sebestyén A, Paku S, et al. Antiproliferative and apoptotic effects of mycophenolic acid in human B-cell non-Hodgkin lymphomas. Leuk Res 31:1003-1008, 1007

2. Végső G, Tóth M, Hídvégi M, et al. Malignancies after renal transplantation during 33 years at a single center. Pathol Oncol Res 13:63-69, 2007

3. Langer RM, Járay J, Tóth A, et al. De novo tumors after kidney transplantation: The Budapest experience. Transplant Proc 35:1396-1398, 2003

4. Végső Gy, Járay J. A veseátültetést követően kialakuló rosszindulatú daganatok. Orvosi Hetilap 148:2115-2113, 2007

5. Végső Gy, Sebestyén A, Járay J, Kopper L. Rosszindulatú daganatok a szervátültetést követő immunszupprimált állapotban. Orvosképzés 3:137-244, 2006

6. Végső Gy, Németh Zs, Péter A, et al. Rosszindulatú szájüregi daganat megjelenése 19 évvel veseátültetést követően. Magyar Onkológia 41:180-183, 1997

\section{A doktori értekezéstől független közlemények}

1. Tóth M, Drabant S, Varga B, et al. Tofisopam inhibits the pharmacokinetics of CYP3A substrate midazolam. Eur J Clin Pharmacol 64:93-94, 2008

2. Végső G, Máthé Z, Péter A, et al. Improving results of renal transplantation with use of elderly donors: The Budapest experience. Transplant Proc 37:4225-4227, 2005 
3. Szende B, Farid P, Végső G, et al. Apoptosis and P53, Bcl-2 and Bax gene expression in parathyroid glands of patients with hyperparathyroidism. Pathol Oncol Res 10:98-103, 2004

4. Végső Gy, Máthé Z, Péter A, et al. Az idős donorokból történt veseátültetés javuló eredményei Budapesten. Hypertonia és Nephrológia 8:186-192, 2004

5. Végső Gy. Évszemle 2000. Sebészet: Daganatsebészet, Endocrin sebészet - mellékpajzsmirigy. Magyar Orvos 9:37, 2001

6. Végső Gy, Tóth M, Péter A, et al. A vesetranszplantáció eredménye 60 év feletti donorokból átültetett graftok esetén. Hypertonia és Nephrológia 4:89-92, 2000

7. Végső Gy, Péter A, Dabasi G, et al. Az endokrinológia sebészi vonatkozásai: hyperparathyreosis miatt operált betegeink. Magyar Sebészet 50:325-329, 1997

8. Végső Gy, Péter A, Árkosy M, et al. Splenectomia, mint a gastrointestinalis vérzés ritka mútéti megoldása. Magyar Sebészet 50:393-395, 1997
9. Péter A, Végső Gy, Máthé Z, Alföldy F. Az Algopyrin helye a mindennapi gyógyításban. Medicus Universalis 30:171-175, 1997

10. Péter A, Végső Gy, Alföldy F, et al. Vesedaganat miatt végzett műtéteink. Magyar Sebészet 50:315-318, 1997

11. Hutás G, Sármán B, Pusztai P, et al. Diabeteses mastopathia 1-es típusú, hosszú ideje fennálló diabetes mellitusban. Diabetol Hung 8:177-182, 2000

12. Szende B, Árvai K, Peták I, et al. Génexpresszió-változások a mellékpajzsmirigy proliferatív folyamata során. Magyar Onkológia 50:137-140, 2006

13. Máthé $\mathrm{Z}$, Görög $\mathrm{D}$, Alföldy F, et al. Az endokrinológia sebészi vonatkozásai: mellékvesedaganat miatt kezelt betegeink. Magyar Sebészet 50:315-318, 1997

14. Nemes B, Alföldy F, Péter A, et al. Benefits of cell saver during the operation of gastric haemorrhage following repeated pancreatitis. Acta Chirurg Hung 36:254-255, 1997 